\title{
Testing assumptions of nitrogen cycling between a temperate, model coral host and its facultative symbiont: symbiotic contributions to dissolved inorganic nitrogen assimilation
}

\author{
L. E. DiRoberts ${ }^{1}$, A. Dudek ${ }^{1,2}$, N. E. Ray $^{1}$, R. W. Fulweiler ${ }^{1,3}$, R. D. Rotjan ${ }^{1, *}$ \\ ${ }^{1}$ Department of Biology, Boston University, Boston, MA 02215, USA \\ ${ }^{2}$ BU Academy, Boston, MA 02215, USA \\ ${ }^{3}$ Department of Earth and Environment, Boston University, Boston, MA 02215, USA
}

\begin{abstract}
Coral symbioses are predicated on the need for mutual nutrient acquisition and translocation between partners. Carbon translocation is well-studied in this classic mutualism, while nitrogen $(\mathrm{N})$ has received comparatively less attention. Quantifying the mechanisms and dynamics of $\mathrm{N}$ assimilation is critical to understanding the functional ecology of coral organisms. Given the importance of symbiosis to the coral holobiont, it is important to determine what role photosynthetic symbionts play in $\mathrm{N}$ acquisition. We used the facultatively symbiotic temperate coral Astrangia poculata and ${ }^{15} \mathrm{~N}$ labeling to test the effects of symbiotic state and trophic status on $\mathrm{N}$ acquisition. We tracked assimilation of 2 forms of isotopically labeled dissolved inorganic $\mathrm{N}$ (DIN: ammonium, ${ }^{15} \mathrm{NH}_{4}{ }^{+}$and nitrate, ${ }^{15} \mathrm{NO}_{3}{ }^{-}$) by fed and starved colonies of both symbiotic and aposymbiotic $A$. poculata. Coral holobiont tissue was subsequently analyzed for $\delta^{15} \mathrm{~N}$ and changes in photosynthetic efficiency. Results suggest that corals acquired the most $\mathrm{N}$ from DIN via their symbiont Breviolum psygmophilum and that $\mathrm{NH}_{4}{ }^{+}$is more readily assimilated than $\mathrm{NO}_{3}{ }^{-}$. Photosynthetic efficiency increased with the addition of $\mathrm{NH}_{4}{ }^{+}$, but only for fed, symbiotic treatments. $\mathrm{NO}_{3}{ }^{-}$adversely affected photosynthetic efficiency among starved corals. Our results suggest that symbiosis is advantageous for DIN acquisition, that dysbiosis inhibits corals' mixotrophic strategy of nutrient acquisition, and that either feeding or symbiosis alone does not fully provide the energetic advantage of both. This study lends support to the emerging hypothesis that symbionts are mutualists in optimal conditions but shift to a parasitic paradigm when resources or energy are scarce.
\end{abstract}

KEY WORDS: Symbiosis $\cdot$ Ammonium $\cdot$ Nitrate $\cdot$ Facultative symbiosis $\cdot$ Nutrients

\section{INTRODUCTION}

Mixotrophy, the derivation of nourishment from both autotrophy and heterotrophy, is common among symbiotic marine organisms. Mixotrophy is most typically represented by nutritional mutualisms, enabling multimodal nutrient acquisition in different environmental contexts (Porter 1976, Muscatine \&

${ }^{*}$ Corresponding author: rrotjan@bu.edu
Porter 1977, Fabricius et al. 1995, Sebens et al. 1997, Houlbrèque \& Ferrier-Pagès 2009). When symbioses break down, classic mutualisms suffer and often result in dysbiosis, which can lead to mortality in one or both partners (Iglesias-Prieto et al. 1992, Kroeker et al. 2010, Huertas et al. 2011). Dysbiosis-driven mortality is commonly observed in reef-building scleractinian corals that are bleaching on a global

() The authors 2021. Open Access under Creative Commons by Attribution Licence. Use, distribution and reproduction are unrestricted. Authors and original publication must be credited. 
scale due to rising seawater temperatures and other consequences of global change (Gates et al. 1992, Hoegh-Guldberg 1999).

Coral symbioses are predicated on the need for mutual nutrient acquisition and translocation between partners (Muscatine \& Porter 1977, Tremblay et al. 2012, 2014). Much like nitrogen (N), the heterotrophic contribution of carbon (C) to the holobiont is also highly variable, ranging from $0-100 \%$ with averages in the $40-60 \%$ range, and acquisition dynamics can be influenced by species, depth, irradiance, trophic plasticity, food availability, and symbiont density (Palardy et al. 2008, Tremblay et al. 2014, Fox et al. 2019, Radice et al. 2019). When dysbiosis occurs, coral hosts become stressed and enter a period of functional starvation (Hoegh-Guldberg 1999). In response, symbiotic hosts either draw upon nutrient reserves (Fitt et al. 1993, Schoepf et al. 2015, Levas et al. 2018) or shift to increased heterotrophy during periods of stress (Palardy et al. 2005, 2008, Grottoli et al. 2006, reviewed by Houlbrèque \& Ferrier-Pagès 2009). However, these triage behaviors are not sustainable in the long term (Grottoli et al. 2006) as most tropical corals have an obligate relationship with their symbionts wherein up to $95 \%$ of autotrophically fixed $\mathrm{C}$ is translocated from the symbiont to the host (McCloskey \& Muscatine 1984, Muscatine et al. 1984, Davies 1991, Davy et al. 1996, Alamaru et al. 2009, Bednarz et al. 2017).

$\mathrm{N}$ is one of the most important nutrients for tissue growth. Corals need N for DNA and protein synthesis (Raymond et al. 2004, Wang \& Douglas 1999), yet $\mathrm{N}$ is often the limiting nutrient in marine ecosystems (Vitousek \& Howarth 1991). Acquisition of $\mathrm{N}$ through $\mathrm{N}$ fixation by diazotrophs within the coral holobiont is an energetically costly process that is likely fueled by $\mathrm{C}$ fixed photosynthetically by Symbiodiniaceae (Cardini et al. 2015). Additionally, the acquisition of dissolved inorganic $\mathrm{N}$ (DIN) (both ammonium, $\mathrm{NH}_{4}{ }^{+}$, and nitrate, $\mathrm{NO}_{3}{ }^{-}$) is fueled by photosynthates within the symbiont and translocated photosynthates within the host (Kopp et al. 2015, Ezzat et al. 2017). Most evidence suggests $\mathrm{NH}_{4}{ }^{+}$is preferred over $\mathrm{NO}_{3}{ }^{-}$for both coral host and algal symbiont (Grover et al. 2002, 2003, 2008, Pernice et al. 2012). Unlike $\mathrm{NO}_{3}{ }^{-}$, which requires a minimum concentration to be met for uptake to occur, $\mathrm{NH}_{4}{ }^{+}$uptake is independent of concentration, though assimilation and concentration are positively correlated (D'Elia \& Webb 1977, Burris 1983, Bythell 1990, Szmant et al. 1990). DIN is assimilated via the glutamine synthetase/glutamine:2 oxoglutarate aminotransferase cycle. Though this enzymatic cycle is commonly thought to be present in both the coral host and symbiont tissue (Yellowlees et al. 1994, 2008, Catmull et al. 1987, Wang \& Douglas 1999), it appears that symbionts have the greater capability for assimilating DIN (Kopp et al. 2013, Leal et al. 2015, Tanaka et al. 2015, Aranda et al. 2016). However, due to the species-specific nature of coral host-symbiont ecology (Ezzat et al. 2016, 2019, Biquand et al. 2017), there is no consensus as to the type of DIN symbiotic corals prefer. The question of what DIN acquisition pathways remain viable against starvation and mortality in corals experiencing dysbiosis as a result of environmental stress is an area of active investigation (e.g. Reynaud et al. 2009, Krueger et al. 2018, Ezzat et al. 2019).

There is growing interest in symbiont ecology as to how $\mathrm{N}$ is acquired under aposymbiotic (primarily heterotrophic) vs. symbiotic (autotrophic + heterotrophic) states in corals. Facultatively symbiotic systems can offer unique opportunities (Cui et al. 2019) to probe the nature of $\mathrm{N}$ acquisition by both autotrophic and heterotrophic pathways independently, in a nonstressed state (Szmant-Froelich \& Pilson 1977, 1984). Recent work has suggested that $\mathrm{N}$ dynamics regulate symbiont growth (Cui et al. 2019) and that $\mathrm{N}$ dynamics are context-dependent by depth and heterotrophic activity (Tilstra et al. 2019). Though these studies hint at the mechanism behind $\mathrm{N}$ use in corals, experimental manipulation of DIN uptake by autotrophic and heterotrophic corals is needed to fully test the hypothesis that coral symbionts control DIN availability or that DIN availability may influence symbiont performance (photosynthetic efficiency).

In this study, we used the facultatively symbiotic coral Astrangia poculata to examine interactions between coral symbiotic state, food availability, and DIN uptake. A. poculata facultatively associates with the endosymbiotic dinoflagellate Breviolum psygmophilum, formerly genus Symbiodinium, Clade B2 (LaJeunesse et al. 2012, 2018). Symbiotic states have previously been assigned according to color, approximate chlorophyll concentration (Dimond \& Carrington 2008, DeFilippo et al. 2016, Sharp et al. 2017, Burmester et al. 2018), and cell density of Symbiodinium in summer months, with brown-colony Symbiodinium densities exceeding 106 cells $\mathrm{cm}^{-2}$ coral tissue, and white-colony Symbiodinium densities ranging from 104-106 cells $\mathrm{cm}^{-2}$ (Sharp et al. 2017). Aposymbiotic colonies are likely more reliant on heterotrophy for energy and nutrition than their symbiotic counterparts. We used a ${ }^{15} \mathrm{~N}$ tracer experiment to identify the forms of DIN $\left(\mathrm{NH}_{4}{ }^{+}\right.$or $\left.\mathrm{NO}_{3}{ }^{-}\right)$that can be taken up by symbiotic and aposymbiotic A. poculata colonies in both starved and fed treatments to manip- 
ulate holobiont need for DIN. Additionally, we measured related impacts on symbiont performance (i.e. photosynthetic efficiency) and host performance (i.e. protein production). This experiment answers 4 key mechanistic, ecologically relevant functional questions: (1) Does the natural $\delta^{15} \mathrm{~N}$ signature differ between symbiotic and aposymbiotic colonies of wildcollected A. poculata, indicative of different sources of colony $\mathrm{N}$ ? (2) Is $\mathrm{NH}_{4}{ }^{+}$or $\mathrm{NO}_{3}{ }^{-}$more readily assimilated by the host, symbiont, or both? (3) Is there a compensatory nutrient-uptake mechanism in the absence of heterotrophy? (4) Is enhanced DIN assimilation associated with more photosynthesis?

\section{MATERIALS AND METHODS}

\subsection{Experimental overview}

Five trials of the same experiment were conducted, with 36 corals trial $^{-1}$ in August and September 2018 for a total of 180 corals tested. Within each trial, corals were placed into one of 3 possible DIN treatments: ${ }^{15} \mathrm{NH}_{4}{ }^{+}$enriched artificial seawater (ASW), ${ }^{15} \mathrm{NO}_{3}{ }^{-}$enriched ASW, or unenriched ASW. Within each treatment, 6 colonies were fed $(3 \mathrm{sym}-$ biotic and 3 aposymbiotic colonies) and 6 were starved (Fig. 1).

\subsection{Coral colony collection and husbandry}

Astrangia poculata coral colonies were collected at Fort Wetherill State Park in Jamestown, RI $\left(41.478^{\circ} \mathrm{N}, 71.359^{\circ} \mathrm{W}\right)$ on 16 July 2018 . For collection, divers targeted corals that were clearly symbiotic or aposymbiotic corals (not mixed); 105 colonies of each were selected for the experiments (210 colonies total).

Corals were acclimated and housed in a recirculating closed tank system filled with Instant Ocean ${ }^{\circledR}$ ASW (Spectrum Brands) and kept on a $12 \mathrm{~h}$ light:12 h dark cycle with no nutrient addition. The life support components of the systems include a fluidized biofilter, UV sterilizer, heat exchanger, protein skimmer, and 2 mechanical filter bags to remove detritus. Tank conditions were monitored for light and temperature using a Seneye Reef Monitor; system-wide conditions were monitored by a CA Digital Aquatics Reefkeeper Elite V2. Temperature was maintained at an average of $21.6 \pm 0.9^{\circ} \mathrm{C}$, mimicking August temperatures in Jamestown, RI (average: $20.9^{\circ} \mathrm{C}_{i}$ https://www. seatemperature.org/), which correspond to the time- frame of the experiment. Photosynthetically active radiation (PAR) was maintained at an average of $89.6 \pm 10.8 \mu \mathrm{mol} \mathrm{m}{ }^{-2} \mathrm{~s}^{-1}$ during daylight conditions. Prior to experimentation, corals were fed frozen nauplii shrimp twice weekly. Tanks and corals were cleaned as needed to prevent algal overgrowth. Each colony was individually labeled, photographed, and later randomly assigned to a condition (starved, fed), treatment $\left({ }^{15} \mathrm{NH}_{4}{ }^{+},{ }^{15} \mathrm{NO}_{3}{ }^{-}\right.$, untreated/negative control), or trial (1-5 temporal replicates).

\subsection{Experimental preparation}

Prior to experimentation and treatment allocation for each trial, 12 corals treatment ${ }^{-1}$ were each preorganized into 3 groups of 4 (quads) and then allocated across conditions (symbiotic fed, symbiotic starved, aposymbiotic fed, aposymbiotic starved) within each treatment. In this way, corals were selected to be morphologically similar in terms of polyp size and interstitial distance between polyps. Using a Dremel rotary saw with a diamond wheel blade, colonies were cut to have 15-25 polyps quad ${ }^{-1}$ and allowed at least $12 \mathrm{~h}$ of recovery time. All cuts were made between polyps, where there is little/no coenenchyme. For each quad, one of each symbiotic state was assigned to be fed or starved, and the entire group was allocated to a $\mathrm{N}$ treatment (control, ${ }^{15} \mathrm{NH}_{4}{ }^{+}$, or ${ }^{15} \mathrm{NO}_{3}{ }^{-}$treated seawater; Fig. 1). There were 5 temporal replicates (trials), and each trial consisted of 3 colony replicates for each symbiotic state

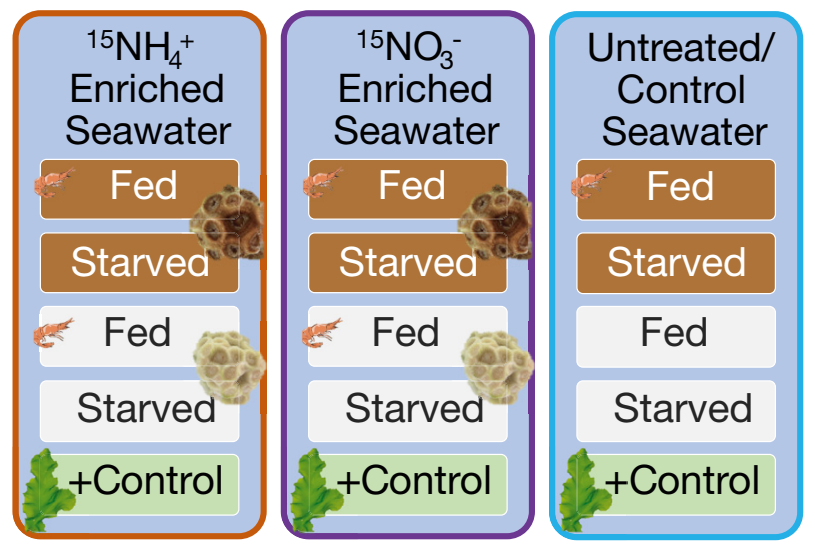

Fig. 1. Experimental design: corals $(\mathrm{n}=15$ per treatment combination) were exposed to $5 \mu \mathrm{M}$ ammonium $\left({ }^{15} \mathrm{NH}_{4}{ }^{+}\right)$ enriched artificial seawater, $5 \mu \mathrm{M}$ nitrate $\left({ }^{15} \mathrm{NO}_{3}{ }^{-}\right)$enriched artificial seawater, or control/untreated artificial seawater. Within each treatment, symbiotic (brown) and aposymbiotic (white) colonies were either fed or starved 
(symbiotic, aposymbiotic) and nutritional condition (fed, starved) across each $\mathrm{N}$ treatment. Five consecutive trials were executed over a $5 \mathrm{wk}$ period from 6 August 2018 to 7 September 2018.

Three days prior to DIN treatment, corals were starved to minimize interference with metabolic cycles during the experiment. To avoid pseudoreplication, each colony was placed in its own $250 \mathrm{ml}$ capacity jar containing $200 \mathrm{ml}$ ASW. Each jar was randomly assigned to a location within a tank that served as a bath with common temperature and light conditions. Jars remained open on top and were given their own individual air stones for aeration and water circulation. All glassware was pre-cleaned in a $10 \% \mathrm{v} / \mathrm{v} \mathrm{HCl}$ acid bath and rinsed thoroughly with deionized water. At the onset of each experiment, each jar was enriched with either $\geq 99 \%{ }^{15} \mathrm{NH}_{4} \mathrm{Cl}$ or $\mathrm{Na}^{15} \mathrm{NO}_{3}$ (Sigma Aldrich) for a final concentration of $5 \mu \mathrm{M}$ of respective enriched DIN jar ${ }^{-1}$ or left unenriched. We elected to amend to $5 \mu \mathrm{M}$ as this concentration is typical of DIN concentrations observed near the ocean-estuary interface in Narragansett Bay (Oviatt et al. 2017). Background DIN levels in the control (unenriched) treatment (made with Instant Ocean) were $0.357 \mu \mathrm{M} \mathrm{NH}_{4}{ }^{+}$and $0.035 \mu \mathrm{M} \mathrm{NO}_{3}{ }^{-}$. Air stones were turned on for $5 \mathrm{~min}$ to circulate treatments and then were briefly turned off for feeding (including for starved corals). Fed corals were fed live Artemia brine shrimp once daily in still water for 10 min and then the air stones were turned back on. The $\delta^{15} \mathrm{~N}$ value of our Artemia was $20.86 \%$. Corals underwent a complete water change (thereby refreshing the labeled DIN treatment) every $24 \mathrm{~h}$ over a total treatment time of $3 \mathrm{~d}$, with new labeled DIN added each day to ensure sufficient supply. The DIN enrichment and experimental duration used was similar in length and intensity to other DIN pulse studies in corals (Grover et al. 2003, Tanaka et al. 2006, Pernice et al. 2012, Kopp et al. 2013, Ezzat et al. 2015).

After $3 \mathrm{~d}$ of treatment, coral tissue was harvested for analysis. A subset of each colony (2-3 polyps each) was flash-frozen in liquid $\mathrm{N}$ for protein analysis. The remaining coral tissue was rinsed thoroughly with standard seawater and removed from the skeleton with a Waterpik ${ }^{\circledR}$ yielding coral tissue slurry, which was frozen at $-4^{\circ} \mathrm{C}$. Samples were later defrosted and centrifuged at $10000 \mathrm{RCF}$ for $5 \mathrm{~min}$ to separate tissue from seawater. The supernatant was decanted, and the coral tissue pellet was dried overnight or until a constant weight was achieved. Dry holobiont tissue was then crushed into a powder and used for stable isotope analysis.

\subsection{Positive control}

A positive control test used the green algae Ulva lactuca, collected at low tide in September 2018 in Salem, MA $\left(42.537^{\circ} \mathrm{N}, 70.867^{\circ} \mathrm{W}\right)$ to confirm that biological uptake of the enriched DIN would be successful in our experimental setup. Algal controls were manually cleaned of epiphytes, laid out flat, and cut into 45 pieces $\left(6.5 \mathrm{~cm}^{2}\right.$ each) from undamaged areas. Each square was placed into a treatment jar with $200 \mathrm{ml}$ of ASW; 15 jars were treated with $5 \mu \mathrm{M}{ }^{15} \mathrm{NH}_{4} \mathrm{Cl}$, 15 with $5 \mu \mathrm{M} \mathrm{Na}{ }^{15} \mathrm{NO}_{3}$, and 15 received no amendment. All samples were treated with the same procedure as previous trials, with 2 exceptions: air stones were not used and samples were not fed Artemia. After $3 \mathrm{~d}$, samples were rinsed thoroughly, dried, ground, and submitted for stable isotope analysis.

\subsection{Measuring photosynthetic efficiency}

Relative rates of photosynthesis for each treatment at the beginning and end of each experiment were estimated using pulse-amplitude modulated (PAM) fluorometry. A Walz Junior PAM meter was used to measure chlorophyll activity as a proxy for photosynthetic efficiency $\left(F_{\mathrm{v}} / F_{\mathrm{m}}\right)$. Corals were darkacclimated for $1 \mathrm{~h}$ prior to measurements being taken. Three polyps per colony were measured and the mean $F_{\mathrm{v}} / F_{\mathrm{m}}$ for that quad was calculated. Initial PAM measurements were taken immediately before DIN treatments were administered. Final PAM measurements were taken after the second full day of $\delta^{15} \mathrm{~N}$ exposure $(61.10 \mathrm{~h})$.

\subsection{Stable isotope and elemental analyses}

Tissue from Trials 3, 4, and 5 was analyzed for $\delta^{15} \mathrm{~N}$ (the ratio of heavy to light isotopes) in the Boston University Stable Isotope Lab (https://www.bu. edu/sil/). This analysis also generated $\delta^{13} \mathrm{C}, \% \mathrm{~N}$ (by mass), \% C (by mass), and C:N ratios (by mass). Samples were dried to a constant weight, encapsulated in $5 \times 9 \mathrm{~mm}$ tin capsules (Costech Analytical Technologies), and then combusted using a Eurovector CN analyzer connected to a continuous flow GV Instruments Isoprime Isotope Ratio Mass Spectrometer. External precision standards were $0.2 \%$ for ${ }^{15} \mathrm{~N}$ and ${ }^{13} \mathrm{C}$, and all data is reported in per mille (\%o) values. Isotope ratios are calibrated to international standards. For ${ }^{13} \mathrm{CV}$-PDB the gas is calibrated against 
NBS 20 (Solnhofen Limestone). For ${ }^{15} \mathrm{~N}_{\text {air }}$ the gas is calibrated against atmospheric $\mathrm{N}_{2}$ and IAEA standards $\mathrm{N}-1, \mathrm{~N}-2$, and $\mathrm{N}-3$ (all are ammonium sulfate standards). Randomly selected technical replicates were conducted on 5 samples to ensure precision, and all were within the min./max. range of other individuals in the same treatment with one exception, which was subsequently excluded from the analysis. Two ${ }^{15} \mathrm{NO}_{3}{ }^{-}$treated samples with unusually high $\delta^{15} \mathrm{~N}$ values due to carryover from previous samples (a known potential issue when processing enriched samples) were considered methodological artefacts and thus eliminated from data analysis.

\subsection{Protein analyses}

Protein concentrations were determined using Bradford protein assay on previously frozen coral tissue. Thawed tissue was removed from the skeleton with a Waterpik ${ }^{\circledR}$, standardized by volume, and homogenized via sonification. Absorbance at $595 \mathrm{~nm}$ for 3 replicates of 24 samples as well as 3 replicates of a serial dilution of BSA (a known protein concentrate) were measured on a single 96 well microplate with a BioTek Synergy H1 microplate reader. A total of 5 plates were used to run all 205 samples. The mean of each of the 3 replicates was calculated via a standard curve based on the albumin standard. The skeleton of each coral fragment was labeled and photographed with a size standard, then used to determine polyp surface area using ImageJ. Final protein concentration was determined as a unit of volume polyp surface area $\left(\mu \mathrm{cm} \mathrm{cm}^{-2}\right)$.

\subsection{Statistical approach}

To compare between treatment groups, we used a mixed model approach using R statistical software (R Core Team 2014) and the 'lme4' package (Bates et al. 2015). To begin, we determined whether the $\delta^{15} \mathrm{~N}$ and protein content data best fit a normal, lognormal, or gamma distribution using the 'fitdistrplus' package (Delignette-Muller \& Dutang 2015, Table S1 in the Supplement at www.int-res.com/articles/suppl/ m670p061_supp.pdf). Following determination of the distribution that best described each data set, we created 2 models. One model contained feeding treatment, symbiotic state, and DIN addition as interacting fixed effects, and the other contained these same fixed effects with the addition of trial as a random effect. In cases where data was not normally dis- tributed, we either log transformed it or shifted it so all points were positive and informed the model the data had a gamma distribution. We then compared the 2 models with and without trial as a random effect using Akaike's information criterion (AIC). In all cases, the simpler model that did not include the random effect had a lower AIC score, indicating trial was not an important effect. We continued the rest of our analysis without including trial as a random effect in our models. We used least square means tests via the 'emmeans' package (Lenth 2018) to investigate pair-wise comparisons between treatments, allowing us to incorporate potential interactive effects in our comparisons (Table S2 in the Supplement). We repeated this approach with data subset by ${ }^{15} \mathrm{~N}$ addition type, creating models that included only feeding treatment and symbiotic state in order to compare how these processes changed within each $\mathrm{N}$ addition treatment (Tables S3 \& S4).

Paired $t$-tests were conducted using Systat (v.11) and GraphPad Prism (v.8.1.0) to test whether photosynthetic efficiency changed throughout the course of the experiment for each treatment type and were Bonferroni-corrected to avoid potential Type II statistical error. See Table S5 in the Supplement for significance test results. We used linear regressions to test for relationships between DIN assimilation of each DIN treatment and change in photosynthetic efficiency.

\subsection{Data availability}

All data used in this study is available in the Dryad digital repository and can be accessed via https://doi. org/10.5061/dryad.brv15dv9q.

\section{RESULTS}

\subsection{Stable isotope analysis}

Ulva lactuca positive controls rapidly incorporated ${ }^{15} \mathrm{~N}$ and assimilated significantly more ${ }^{15} \mathrm{NO}_{3}{ }^{-}$(mean \pm SE: $5371.1 \pm 437.9 \%$; $\mathrm{p}<0.001)$ than ${ }^{15} \mathrm{NH}_{4}{ }^{+}(4016.9 \pm$ 118.0\%; Fig. 2, Table 1).

Wild collected (untreated) aposymbiotic corals had significantly higher naturally occurring ${ }^{15} \mathrm{~N}(15.3 \pm$ $0.2 \%$ o) than untreated symbiotic corals $(12.4 \pm 0.4 \%)$. Among symbiotic fed corals, those treated with ${ }^{15} \mathrm{NH}_{4}{ }^{+}$were the most enriched in ${ }^{15} \mathrm{~N}(562.3 \pm$ $52.0 \%$ ) followed by ${ }^{15} \mathrm{NO}_{3}{ }^{-}$treated corals (172.9 \pm $27.7 \%$ ) and untreated corals $(12.7 \pm 0.5 \%$ ). Among symbiotic starved corals, those treated with ${ }^{15} \mathrm{NH}_{4}{ }^{+}$ 


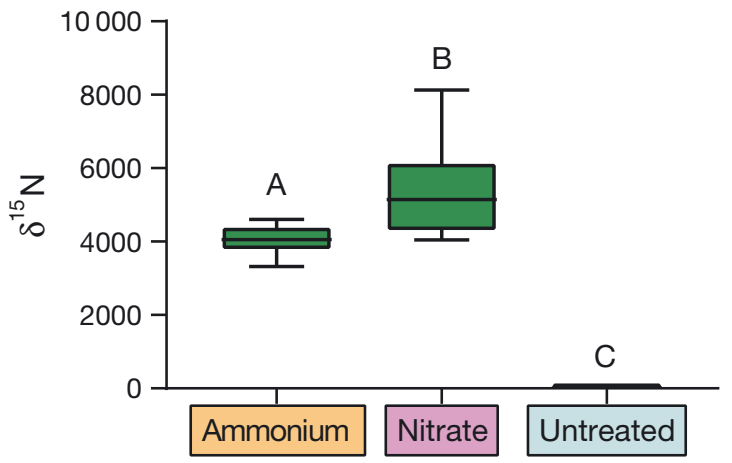

Fig. 2. Levels of $\delta^{15} \mathrm{~N}$ in Ulva lactuca tissue (positive control) in ${ }^{15} \mathrm{~N}$ ammonium treated water, ${ }^{15} \mathrm{~N}$ nitrate treated water, and untreated water. The box extends from the $25^{\text {th }}$ to the $75^{\text {th }}$ percentiles; centerline: median; whiskers: min. to max. values. Different letters denote statistically significant differences $(\mathrm{p} \leq 0.05)$ following a 1-way ANOVA with a post hoc multiple comparison test $(\mathrm{SS}=151915289, F=135.9$,

$$
\mathrm{df}=2,28, \mathrm{p}<0.001)
$$

$\left(509.0 \pm 64.2 \%\right.$ ) showed a much greater level of ${ }^{15} \mathrm{~N}$ enrichment than ${ }^{15} \mathrm{NO}_{3}{ }^{-}$treated corals (47.3 \pm $13.2 \%$ o) and untreated corals $(12.1 \pm 0.5 \%$ ). This pattern also held for aposymbiotic fed corals $\left({ }^{15} \mathrm{NH}_{4}{ }^{+}\right.$: $321.3 \pm 39.5 \%$; ${ }^{15} \mathrm{NO}_{3}{ }^{-}: 40.8 \pm 12.4 \%$; untreated: $15.0 \pm 0.3 \%$ ). Aposymbiotic starved corals had the lowest enrichment of ${ }^{15} \mathrm{~N}$ for both ${ }^{15} \mathrm{NH}_{4}{ }^{+}(66.0 \pm$ $38.5 \%)$ and ${ }^{15} \mathrm{NO}_{3}{ }^{-}(23.0 \pm 2.6 \%)$ treatments and were the closest in value to untreated aposymbiotic starved corals $(15.6 \pm 0.3 \%$ ) (Table 1$)$.

Within the ${ }^{15} \mathrm{NH}_{4}{ }^{+}$treatment, symbiotic fed corals were significantly more enriched than aposymbiotic fed $(\mathrm{p}=0.003)$ and aposymbiotic starved $(\mathrm{p}<0.001)$ corals. Symbiotic starved corals were also significantly more enriched than aposymbiotic fed $(p=0.038)$ and aposymbiotic starved $(\mathrm{p}<0.001)$ corals. Aposymbiotic fed corals were significantly more enriched than aposymbiotic starved $(\mathrm{p}=0.002)$ corals (Fig. 3 top panel, Table S3). Within the ${ }^{15} \mathrm{NO}_{3}{ }^{-}$ treatment, symbiotic fed colonies were significantly more enriched in ${ }^{15} \mathrm{~N}$ than symbiotic starved corals $(\mathrm{p}=0.004)$, aposymbiotic fed colonies $(\mathrm{p}=0.001)$, and aposymbiotic starved colonies $(\mathrm{p}=$ 0.002; Fig. 3 middle panel, Table S3).

\subsection{Coral protein content}

There was a significant difference between symbiotic and aposymbiotic corals across all treatments $(p=0.013$; Table S2), most likely driven by the increased protein observed in symbi- otic starved corals compared to aposymbiotic fed corals in the ${ }^{15} \mathrm{NH}_{4}{ }^{+}$enriched seawater treatment ( $p=0.018$; Fig. S1, Table S4 in the Supplement).

\subsection{Other nutritional variables}

Measurements of $\mathrm{C}: \mathrm{N}, \delta^{13} \mathrm{C}$, and $\% \mathrm{~N}$ showed no significant differences for any variables (Figs. S2, S3 \& S5 in the Supplement). Symbiotic fed corals in the ${ }^{15} \mathrm{NH}_{4}{ }^{+}$treatment showed a greater \%C than aposymbiotic fed corals in the same treatment (Fig. S4). Means and standard errors are shown in Table S6 in the Supplement.

\subsection{Coral photosynthetic efficiency}

Within the ${ }^{15} \mathrm{NH}_{4}{ }^{+}$treatment (Fig. 4 top row), symbiotic fed corals showed a significant increase in photosynthetic efficiency over the course of the $3 \mathrm{~d}$ treatment ( $p=0.004$; Table S5 in the Supplement). Symbiotic starved corals showed a trend towards increased photosynthetic efficiency $(\mathrm{p}=$ 0.060; Table S5). There were no significant differences in ${ }^{15} \mathrm{NH}_{4}{ }^{+}$treated aposymbiotic fed $(\mathrm{p}=0.548$; Table S5) and ${ }^{15} \mathrm{NH}_{4}{ }^{+}$treated aposymbiotic starved corals ( $p=0.702$; Table S5).

In the $\mathrm{NO}_{3}{ }^{-}$treatment (Fig. 4 middle row), symbiotic starved corals showed a significant decrease in photosynthetic efficiency over the course of the $3 \mathrm{~d}$ treatment ( $p=0.034$; Table S5). Aposymbiotic starved corals showed a declining trend in photosynthetic efficiency ( $p=0.088$; Table S5), whereas symbiotic ( $p=0.978 ;$ Table S5) and aposymbiotic fed corals showed no significant changes over the course of treatment ( $\mathrm{p}=0.168$; Table S5).

Table 1. Mean and standard error of the mean for $\delta^{15} \mathrm{~N} \%$ for all symbiotic states and nutritional states within the ${ }^{15} \mathrm{NH}_{4}{ }^{+}$enriched artificial seawater (ASW) treatments, ${ }^{15} \mathrm{NO}_{3}^{-}$enriched ASW treatments, and unenriched ASW treatments

\begin{tabular}{|c|c|c|c|c|c|c|}
\hline & \multicolumn{2}{|c|}{$\underset{\left({ }^{15} \mathrm{NH}_{4}^{+}\right)}{\text {Ammonium }}$} & \multicolumn{2}{|c|}{$\begin{array}{l}\text { Nitrate } \\
\left({ }^{15} \mathrm{NO}_{3}^{-}\right)\end{array}$} & \multicolumn{2}{|c|}{$\begin{array}{c}\text { Untreated/ } \\
\text { control }\end{array}$} \\
\hline & $\begin{array}{l}\text { Mean } \\
(\%)\end{array}$ & $\begin{array}{c}\text { SEM } \\
(\%)\end{array}$ & $\begin{array}{l}\text { Mean } \\
(\%)\end{array}$ & $\begin{array}{l}\text { SEM } \\
(\%)\end{array}$ & $\begin{array}{l}\text { Mean } \\
(\% \circ)\end{array}$ & $\begin{array}{l}\text { SEM } \\
(\%)\end{array}$ \\
\hline Symbiotic fed & 562.3 & 52.0 & 172.9 & 27.7 & 12.7 & 0.5 \\
\hline Symbiotic starved & 509.0 & 64.2 & 47.3 & 13.2 & 12.1 & 0.5 \\
\hline All symbiotic & 535.6 & 40.6 & 106.4 & 21.2 & 12.4 & 0.4 \\
\hline Aposymbiotic fed & 321.3 & 39.5 & 40.8 & 12.4 & 15.0 & 0.3 \\
\hline Aposymbiotic starved & 66.0 & 38.5 & 23.0 & 2.6 & 15.6 & 0.3 \\
\hline All aposymbiotic & 193.7 & 40.9 & 32.4 & 6.9 & 15.3 & 0.2 \\
\hline All corals & 364.7 & 40.5 & 69.4 & 12.7 & 13.9 & 0.3 \\
\hline Ulva lactuca & 4016.9 & 118.0 & 5371.1 & 437.9 & 11.0 & 0.4 \\
\hline
\end{tabular}



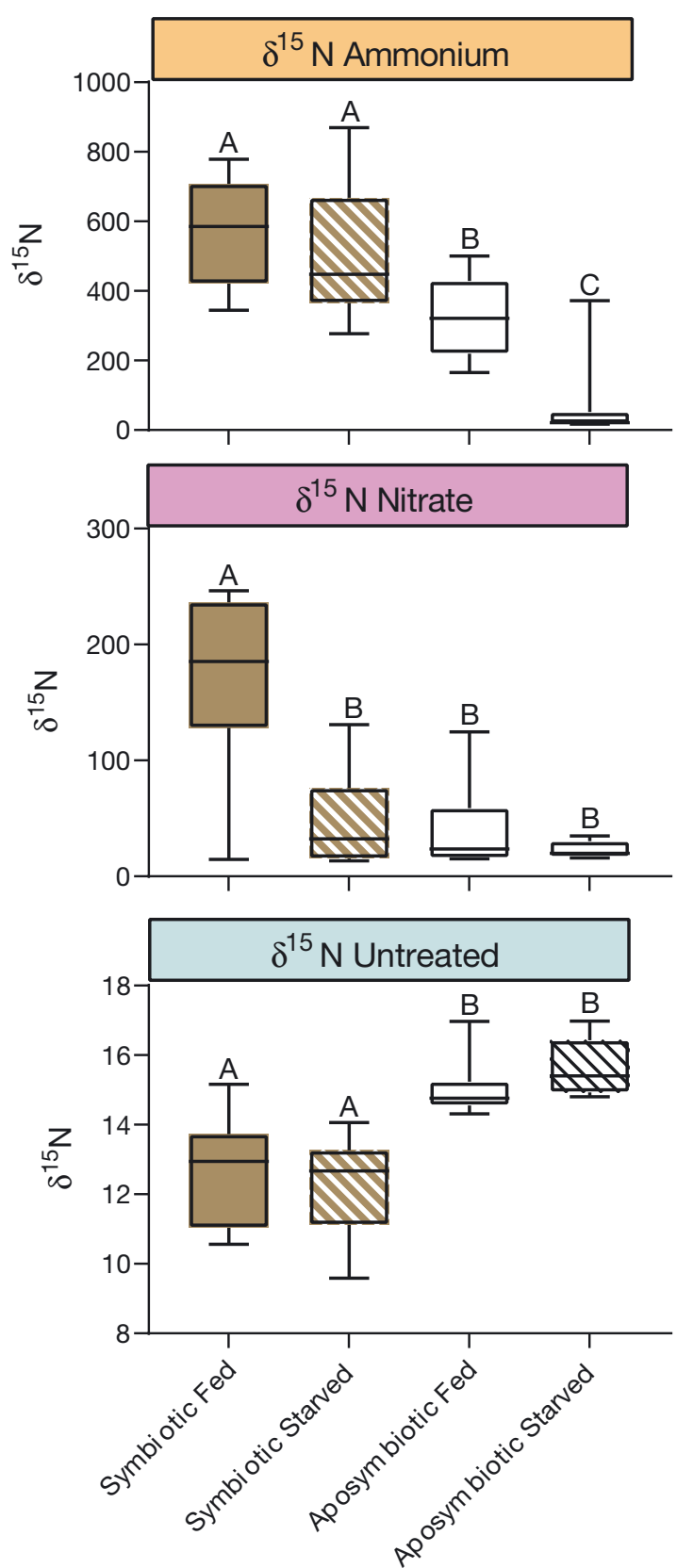

Fig. 3. $\delta^{15} \mathrm{~N}$ enrichment in symbiotic and aposymbiotic, fed and starved Astrangia poculata colonies treated with either ammonium $\left({ }^{15} \mathrm{NH}_{4}{ }^{+}\right)$enriched ASW, nitrate $\left({ }^{15} \mathrm{NO}_{3}{ }^{-}\right)$enriched ASW, or unenriched ASW. The box extends from the 25th to the 75th percentiles; centerline: median; whiskers: min. to max. values. Different letters denote significant differences $(p \leq 0.05)$ following best fit distribution analysis and a pairwise comparison (Tables S2 \&S3). $n=15$ for each treatment, except $\mathrm{n}=14$ for fed symbiotic colonies and starved aposymbiotic colonies treated with nitrate

Untreated/negative control starved corals (Fig. 4 bottom row) showed a significant increase in photosynthetic efficiency over the course of the $3 \mathrm{~d}$ treatment in both symbiotic ( $p<0.001$; Table S5) and aposymbiotic ( $p=0.008$; Table S5) corals. Untreated symbiotic fed corals ( $\mathrm{p}=0.649$; Table S5) and untreated aposymbiotic fed corals $(p=0.981$; Table S5) showed no significant changes over the course of the $3 \mathrm{~d}$ treatment time.

Linear regressions found a significant positive relationship between change in $F_{\mathrm{v}} / F_{\mathrm{m}}$ and $\delta^{15} \mathrm{~N}$ enrichment for colonies treated with ${ }^{15} \mathrm{NH}_{4}{ }^{+}\left(\mathrm{R}^{2}=0.202, \mathrm{p}=\right.$ 0.006), but not ${ }^{15} \mathrm{NO}_{3}{ }^{-}\left(\mathrm{R}^{2}<0.001, \mathrm{p}=0.949\right)$, or untreated colonies $\left(\mathrm{R}^{2}=0.072, \mathrm{p}=0.113\right.$; Fig. 5$)$.

\section{DISCUSSION}

The aim of this study was to explore nutrient acquisition pathways in corals and their symbionts under several $\mathrm{N}$-availability, symbiotic state, and heterotrophy/autotrophy scenarios. This experiment answers 4 key mechanistic, ecologically relevant functional questions: (1) natural abundance $\delta^{15} \mathrm{~N}$ values are higher in aposymbiotic colonies of wild-collected Astrangia poculata than in symbiotic colonies; (2) $\mathrm{NH}_{4}{ }^{+}$is more readily assimilated than $\mathrm{NO}_{3}{ }^{-}$by both symbiotic and aposymbiotic colonies; (3) there is no evidence of compensatory nutrient uptake in the absence of heterotrophy, instead, fed corals are more able to absorb and utilize $\mathrm{N}_{\text {; }}$ and (4) enhanced DIN assimilation is associated with greater photosynthetic efficiency for $\mathrm{NH}_{4}{ }^{+}$.

Our analysis of $A$. poculata suggests that $\mathrm{NH}_{4}{ }^{+}$is the preferred DIN source and the symbiont, Breviolum psygmophilum, is the major $\mathrm{N}$-assimilator, similar to other isotope enrichment studies. The mechanism underlying this response could be the symbiont mediating the host or direct symbiont assimilation, but the holobiont clearly takes up more $\mathrm{NH}_{4}{ }^{+}$regardless of trophic condition. The major contribution of our study is the insight into heterotrophic versus autotrophic dynamics. We observed that food availability influenced DIN uptake in the ${ }^{15} \mathrm{NH}_{4}{ }^{+}$treatment where fed corals showed greater DIN uptake than their starved counterparts regardless of symbiotic state, and in the ${ }^{15} \mathrm{NO}_{3}{ }^{-}$treatment where symbiotic fed corals showed greater DIN uptake than symbiotic starved corals. The behavior of the symbiont in response to different DIN and food availability treatments suggests different energetic and metabolic tradeoffs whereby symbiosis can provide mutualistic benefits, or parasitic costs, to hosts under different scenarios. Our study lends support to the emerging hypothesis that symbionts are mutualists in optimal conditions in which photosynthates derived by the symbiont are shared with the host but shift to para- 

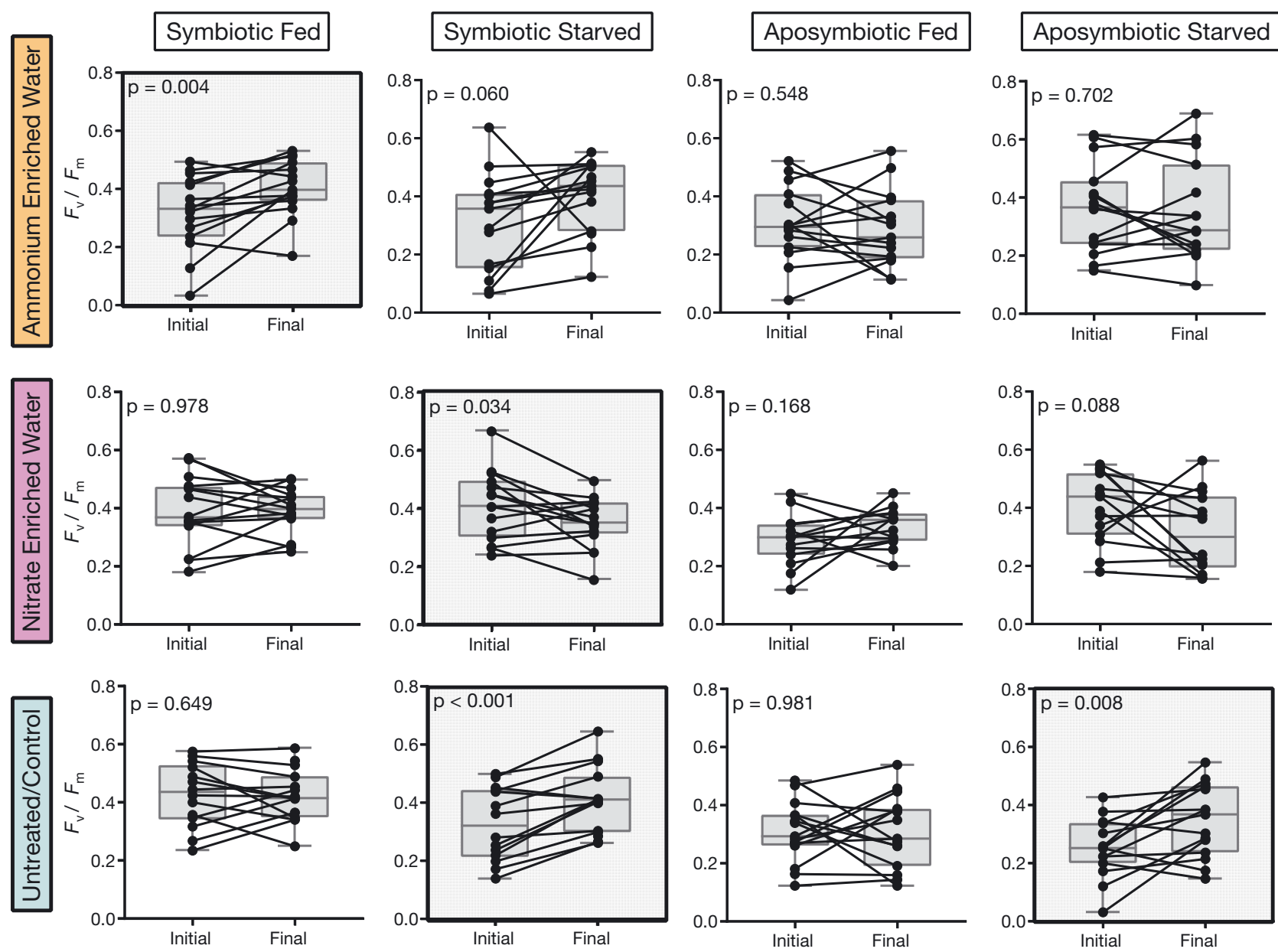

Fig. 4. Photosynthetic efficiency in symbiotic and aposymbiotic, fed and starved Astrangia poculata colonies treated with either ammonium $\left({ }^{15} \mathrm{NH}_{4}{ }^{+}\right.$; top row) enriched ASW, nitrate $\left({ }^{15} \mathrm{NO}_{3}{ }^{-}\right.$; middle row) enriched ASW, or unenriched ASW (bottom row). The box extends from the 25th to the 75th percentiles; centerline: median; whiskers: min. to max. values. Individual colony response is plotted as points overlaying the box plots, showing the difference between initial and final time points for symbiotic or aposymbiotic, fed or starved corals. Heavy-outlined shaded boxes denote significant differences $(p \leq 0.05)$ following a paired $t$-test (Table S5)

sitic nutrition when scarcity of resources or energy causes the symbionts to retain their photosynthates, forcing the host to rely on stored lipids for energy in order to maintain their symbiont population (SzmantFroelich \& Pilson 1980, Baker et al. 2018).

The dynamics of DIN assimilation during enrichment is fundamentally different than what is found in the natural environment. Experimental corals that were not treated with enriched DIN were used to approximate natural abundances of ${ }^{15} \mathrm{~N}$ in wild facultatively symbiotic corals. We observed that aposymbiotic corals had a higher \%o $\delta^{15} \mathrm{~N}$ value than symbiotic corals. This supports either the assumption that aposymbiotic corals are more dependent on heterotrophy than their symbiotic counterparts due to the preferential storage of ${ }^{15} \mathrm{~N}$ in tissue resulting in a bioaccumulation effect (DeNiro \& Epstein 1978,
Peterson \& Fry 1987) or the theory that internal recycling of ${ }^{14} \mathrm{~N}$ back and forth between the coral host tissue and symbiont makes heterotrophically derived $\mathrm{N}$ less necessary and drives the $\delta^{15} \mathrm{~N}$ value down (Muscatine \& D'Elia 1978, Reynaud et al. 2009, Bednarz et al. 2017).

It is reasonable to expect that temperate corals exposed to seasonal shifts in temperature, light, and nutrient availability may obtain $\mathrm{N}$ differently than corals found in warm, stable, oligotrophic tropical waters. For example, Cladocora caespitosa is a symbiotic temperate Mediterranean coral with a high rate of heterotrophic feeding that is exposed to shifting seasonal conditions with corresponding variability of $\delta^{15} \mathrm{~N}$ and $\delta^{13} \mathrm{C}$ suggesting reliance on heterotrophy in the winter (Ferrier-Pagès et al. 2011). Oculina arbuscula, a temperate facultatively 

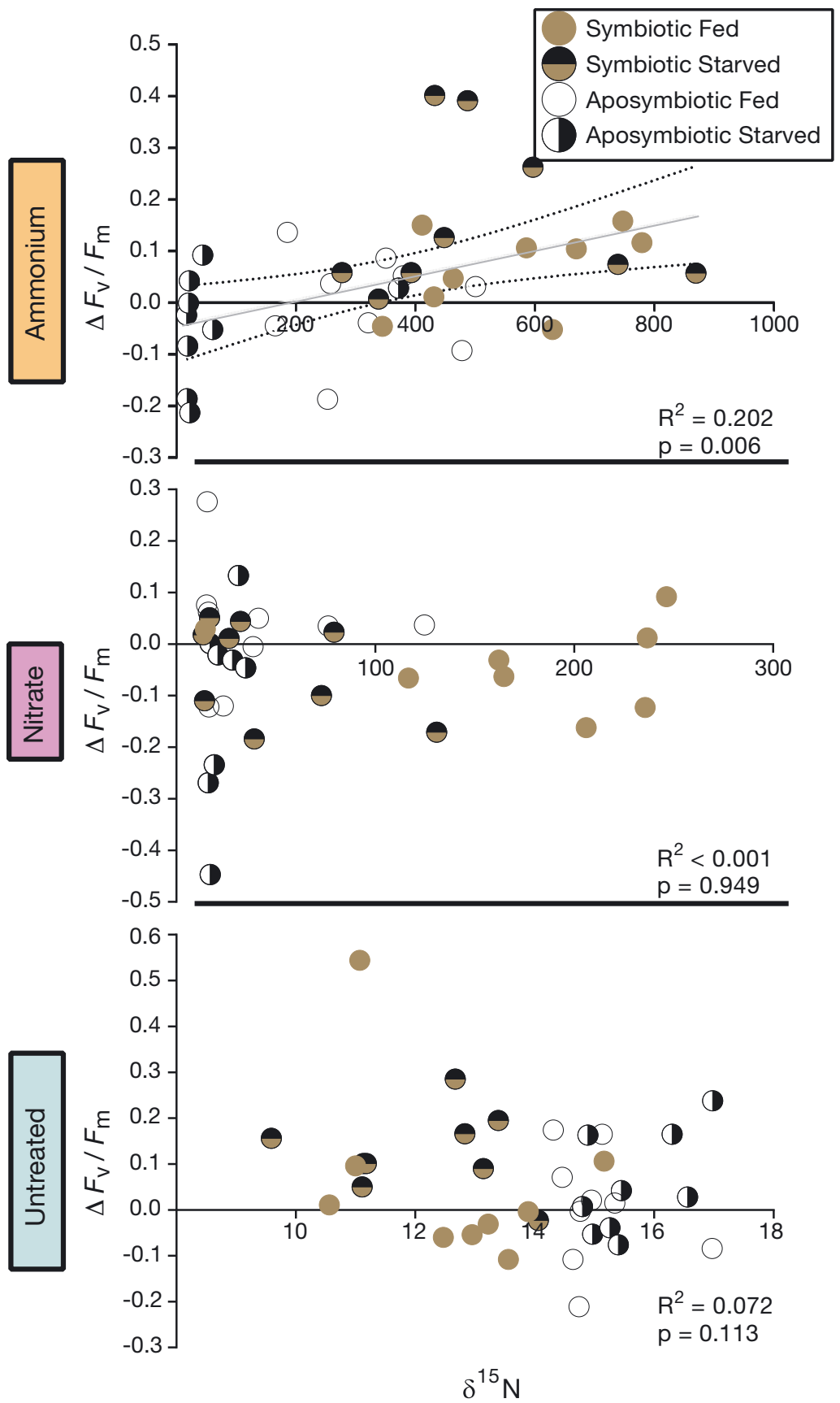

Fig. 5. Relationship between dissolved nitrogen assimilation $\left(\delta^{15} \mathrm{~N}\right)$ and change in photosynthetic efficiency $\left(\Delta F_{\mathrm{v}} / F_{\mathrm{m}}\right)$ for corals treated with ammonium $\left({ }^{15} \mathrm{NH}_{4}{ }^{+} ;\right.$top), nitrate $\left({ }^{15} \mathrm{NO}_{3}{ }^{-} ;\right.$middle), or unenriched ASW (bottom). $\mathrm{R}^{2}$ and $\mathrm{p}$-values from linear regressions with all treatments pooled are shown, with a $95 \%$ confidence interval for significant $(p \leq 0.05)$ relationships

symbiotic coral, exhibited $\delta^{15} \mathrm{~N}$ levels indicative of autotrophic assimilation of DIN regardless of season for both symbiotic and aposymbiotic colonies (Leal et al. 2014). Thus, differences in the assimilation of DIN by temperate corals over seasons is not fully reconciled and may be more complex than previously appreciated.

Although our experimental A. poculata were able to assimilate DIN from the environment in both the ${ }^{15} \mathrm{NH}_{4}{ }^{+}$ and ${ }^{15} \mathrm{NO}_{3}{ }^{-}$treatments, ${ }^{15} \mathrm{NH}_{4}{ }^{+}$was incorporated noticeably more than ${ }^{15} \mathrm{NO}_{3}{ }^{-}$in symbiotic fed corals. Like existing literature (Grover et al. 2002, 2003, Pernice et al. 2012, Kopp et al. 2013, Tanaka et al. 2015), our ${ }^{15} \mathrm{NH}_{4}{ }^{+}$ trials indicate that symbionts are most efficient at $\mathrm{NH}_{4}{ }^{+}$assimilation, further substantiating the important role they play in DIN acquisition (Tanaka et al. 2015, Bednarz et al. 2017). Additional studies have shown that Symbiodinium microadriaticum have high numbers of $\mathrm{NH}_{4}{ }^{+}$transporter domains (genes that promote $\mathrm{C}$ and $\mathrm{N}$ transport and provisioning), which likely help in the translocation of nutrients (Aranda et al. 2016). In contrast, Acropora palmata and its associated symbionts assimilate both $\mathrm{NH}_{4}{ }^{+}$and $\mathrm{NO}_{3}{ }^{-}$ and exhibit diurnal variation in $\mathrm{NO}_{3}{ }^{-}$ uptake, with daytime $\mathrm{NO}_{3}{ }^{-}$assimilation rates higher than $\mathrm{NH}_{4}{ }^{+}$(Bythell 1990). Together, these studies suggest that DIN uptake and DIN assimilation dynamics are not universal and may be highly dependent on coral and symbiont species.

We found that $\mathrm{NO}_{3}{ }^{-}$uptake differed from $\mathrm{NH}_{4}{ }^{+}$uptake in 2 ways: it was lower in general, and only symbiotic fed corals showed any significant uptake. These results indicate either energetic costs or time delays associated with reducing $\mathrm{NO}_{3}{ }^{-}$to $\mathrm{NH}_{4}{ }^{+}$so that it may be taken up by glutamine synthetase enzymes. This observation is similar to other studies in which energetically costly $\mathrm{NO}_{3}{ }^{-}$reduction and uptake has been shown to happen only after available $\mathrm{NH}_{4}{ }^{+}$has been depleted (Berges at al. 1995) and that time delays of $15-30 \mathrm{~min}$ have been shown to occur between $\mathrm{NO}_{3}{ }^{-}$introduction and uptake by coral symbionts (Kopp et al. 2015). Furthermore, it has been suggested that only symbionts, and not the coral host, have the ability to reduce $\mathrm{NO}_{3}{ }^{-}$to $\mathrm{NH}_{4}{ }^{+}$(Crossland \& Barnes 1977, 
Grover et al. 2003). If $\mathrm{NO}_{3}{ }^{-}$reduction costs the coral holobiont energy, colonies not able to acquire energy from both heterotrophy (i.e. Artemia) and autotrophy (photosynthates) might not have had enough available energy for that process. As such, symbiont assimilation of $\mathrm{NO}_{3}{ }^{-}$may only occur under nearly ideal conditions when the host is able to fully meet the energetic requirements of the symbiont for photosynthesis.

If DIN uptake does benefit the symbiont, an increase in photosynthetic efficiency would be expected. Our results show direct evidence for increased photosynthetic efficiency in symbiotic, fed corals in response to ${ }^{15} \mathrm{NH}_{4}{ }^{+}$enriched water, suggesting that symbionts react positively to $\mathrm{NH}_{4}{ }^{+}$availability with an immediate photosynthetic payoff. Correspondingly, our results also clearly show a decrease in photosynthetic efficiency when exposed to ${ }^{15} \mathrm{NO}_{3}{ }^{-}$ enriched water in symbiotic starved corals, which provides insight into the energetic costs of $\mathrm{NO}_{3}{ }^{-}$ assimilation by the symbiont. Starved corals may not be able to provide their symbionts with the energy necessary to reduce $\mathrm{NO}_{3}{ }^{-}$into a usable form (i.e. $\mathrm{NH}_{4}{ }^{+}$) (Ezzat et al. 2019, Rädecker et al. 2019). The coral host may even start to parasitize energy from the symbiont when starved due to the lack of mutualistic benefit as well as the extra energy expenditure of $\mathrm{NO}_{3}{ }^{-}$reduction. While it is possible that endolithic algae within the coral skeleton may also contribute to holobiont $\mathrm{C}$ fixation, the extent of this contribution is still relatively unknown and likely minor compared to the contribution from Symbiodiniaceae (Shashar \& Stambler 1992, Schlichter et al. 1995, 1997, Shashar et al. 1997, Fine \& Loya 2002, Sangsawang et al. 2017).

Further evidence for energetic limitation in A. poculata was observed in the ${ }^{15} \mathrm{NH}_{4}{ }^{+}$trials, where aposymbiotic corals with few symbionts were only successful at assimilating ${ }^{15} \mathrm{NH}_{4}{ }^{+}$when fed. In previous studies, aposymbiotic $A$. poculata corals were able to heal wounded surface areas more effectively when fed, and starved aposymbiotic corals were never able to fully recover from wounding (Burmester et al. 2018). We found that starved, aposymbiotic corals were unable to assimilate $\mathrm{NH}_{4}{ }^{+}$, suggesting that environmental nutrients are inaccessible by the holobiont when there is no autotrophic and heterotrophic energy. This suggestion is further supported by our observations that there were no significant differences in protein levels in the control or ${ }^{15} \mathrm{NO}_{3}{ }^{-}$treatments, likely because excess $\mathrm{N}$ was not available (control) or not accessible $\left({ }^{15} \mathrm{NO}_{3}{ }^{-}\right)$. However, in the ${ }^{15} \mathrm{NH}_{4}{ }^{+}$treatment, symbiotic starved colonies had the highest protein levels across all treatments. As such, A. poculata holobionts may upregulate their protein production via symbiont assimilation of DIN in response to host starvation stress. This effect could be compounded by increased protein retention via host-symbiont nutrient translocation, and future studies could further investigate the role of $\mathrm{N}$ availability in protein production in this and other facultatively symbiotic systems. It is likely that in the absence of any food source (heterotrophic or autotrophic), aposymbiotic corals undergo initial stages of nutritional quiescence (dormancy), experiencing polyp withdrawal and a general cessation of movement and behavior (R. D. Rotjan \& A. Breef-Pilz pers. obs.). As such, these corals would likely be unable to perform the enzymatic processes to assimilate DIN. Nutritional quiescence may be similar to temperature-induced, cold-water quiescence (Grace 2017, Sharp et al. 2017), wherein corals stop exhibiting polyp extension behavior in winter temperatures. Although our enriched DIN experiments were shortterm $(3 \mathrm{~d})$, the observed changes in protein might reflect an organismal response to starvation stress in the presence of available $\mathrm{N}$, but more research is needed.

Measurements of photosynthetic efficiency are often used as a proxy for symbiont population growth and health (Beer et al. 1998, Ralph et al. 1999, Warner et al. 1999). In the context of coral bleaching, there is some evidence that stress can cause one mutualistic partner to turn parasitic towards another, further contributing to dysbiosis events (Baker et al. 2018). Except for our ${ }^{15} \mathrm{NH}_{4}{ }^{+}$enrichment treatments, where DIN was readily assimilated, photosynthetic efficiency differed the most between symbiotic and aposymbiotic corals in starved treatments (for both ${ }^{15} \mathrm{NO}_{3}{ }^{-}$and control), which may indicate that the stress of starvation catalyzes a switch from mutualism to parasitism. In A. poculata, the hosts rely heavily on heterotrophy for nutrient acquisition (SzmantFroelich \& Pilson 1980). Under increased metabolic demand and starvation stress, symbionts may be unable to photosynthesize as efficiently (as in the case of energetically costly $\mathrm{NO}_{3}{ }^{-}$reduction), functionally depriving the host of energetic resources to meet its own energetic requirements. Symbionts may also have the ability to increase their photosynthetic efficiency to compensate for a lack of food/nutrition even when no additional DIN is available as long as there is no energetically prohibitive process occurring. This can be seen in the control groups for symbiotic starved and aposymbiotic starved corals, which each saw a significant increase in photosyn- 
thetic efficiency. Too much DIN in the environment can cause excessive symbiont cell growth, which may deprive corals of nutrition (Lesser et al. 2013), and can lead to phosphorus limitation within corals, reducing stress tolerance and photosynthetic efficiency (D'Angelo \& Wiedenmann 2014, Ezzat et al. 2015). Increased symbiont growth can also lead to a decrease in calcification as more $\mathrm{C}$ is kept in the symbiont and not shared with the host, reducing the availability of $\mathrm{C}$ to make the calcium carbonate skeleton (Reynaud et al. 2003). To prevent this from happening, corals have mechanisms to self-regulate symbiont growth rates and concentrations by withholding excess nutrients from their symbionts (Rees 1991, D'Angelo \& Wiedenmann 2014).

Global sea surface temperature changes are driving a major ecological crisis for coral reefs, causing bleaching events and mortality. It is well established that coral photosynthetic endosymbionts can fix C and are the driving force behind $\mathrm{C}$ acquisition for corals (Muscatine \& Cernichiari 1969, Muscatine \& Porter 1977, Erez 1978, Falkowski et al. 1984, Gattuso et al. 1999). However, dysbiosis not only deprives corals of $\mathrm{C}$ but also of $\mathrm{N}$ and other essential nutrients (Miller \& Yellowlees 1989). The emerging finding of this study is that symbionts, either directly or indirectly, are the driving force behind successful $\mathrm{N}$ acquisition. In nature, aposymbiotic temperate corals likely only thrive because they exist in a nutrient-rich environment with abundant particulate and dissolved organic matter for consumption. Despite being mixotrophic, our study suggests that within the coral holobiont, the autotrophic contribution is extremely valuable even in highly heterotrophic species. Further studies into host regulation of $\mathrm{N}$ cycling could be key to understanding the full extent of the effects of bleaching on coral nutrient cycling.

Acknowledgements. The authors are grateful to the Boston University Initiative on Cities for seed funding that led to this work. Authors are additionally thankful to Robert Michener and the BU stable isotope facility for analysis. Authors are also grateful to Sean Mullen and Adrien Finzi for helpful discussions related to this work, and to Cara Johnson for husbandry assistance. Authors are further grateful to members of the Rotjan Lab, past and present, for their assistance, helpful discussions, and support.

\section{LITERATURE CITED}

Alamaru A, Yam R, Shemesh A, Loya Y (2009) Trophic biology of Stylophora pistillata larvae: evidence from stable isotope analysis. Mar Ecol Prog Ser 383:85-94
Aranda M, Li Y, Liew Y, Baumgarten S and others (2016) Genomes of coral dinoflagellate symbionts highlight evolutionary adaptations conducive to a symbiotic lifestyle. Sci Rep 6:39734

*Baker DM, Freeman CJ, Wong JC, Fogel ML, Knowlton N (2018) Climate change promotes parasitism in a coral symbiosis. ISME J 12:921-930

Bates D, Maechler M, Bolker B, Walker S (2015) Fitting linear mixed-effects models using lme4. J Stat Softw 67:1-48

* Bednarz VN, Grover R, Maguer J, Fine M, Ferrier-Pagès C (2017) The assimilation of diazotroph-derived nitrogen by scleractinian corals depends on their metabolic status. MBio 8:e02058-16

Beer S, Ilan M, Eshel A, Weil A, Brickner I (1998) Use of pulse amplitude modulated (PAM) fluorometry for in situ measurements of photosynthesis in two Red Sea faviid corals. Mar Biol 131:607-612

* Berges JA, Cochlan WP, Harrison PJ (1995) Laboratory and field responses of algal nitrate reductase to diel periodicity in irradiance, nitrate exhaustion, and the presence of ammonium. Mar Ecol Prog Ser 124:259-269

* Biquand E, Okubo N, Aihara Y, Rolland V and others (2017) Acceptable symbiont cell size differs among cnidarian species and may limit symbiont diversity. ISME J 11: 1702-1712

* Burmester EM, Breef-Pilz A, Lawrence NF, Kaufman L, Finnerty JR, Rotjan RD (2018) The impact of autotrophic versus heterotrophic nutritional pathways on colony health and wound recovery in corals. Ecol Evol 8: 10805-10816

Burris RH (1983) Uptake and assimilation of ${ }^{15} \mathrm{NH}_{4}{ }^{+}$by a variety of corals. Mar Biol 75:151-155

*Bythell JC (1990) Nutrient uptake in the reef-building coral Acropora palmata at natural environmental concentrations. Mar Ecol Prog Ser 68:65-69

* Cardini U, Bednarz VN, Naumann MS, van Hoytema N and others (2015) Functional significance of dinitrogen fixation in sustaining coral productivity under oligotrophic conditions. Proc R Soc B 282:20152257

* Catmull J, Yellowlees D, Miller DJ (1987) NADP+-dependent glutamate dehydrogenase from Acropora formosa: purification and properties. Mar Biol 95(4):559-563

Crossland CJ, Barnes DJ (1977) Nitrate assimilation enzymes from two hard corals, Acropora acuminata and Goniastrea australensis. Comp Biochem Physiol B Biochem Mol Biol 57:151-157

Cui G, Liew YJ, Li Y, Kharbatia N and others (2019) Hostdependent nitrogen recycling as a mechanism of symbiont control in Aiptasia. PLOS Genet 15:e1008189

* D'Angelo C, Wiedenmann J (2014) Impacts of nutrient enrichment on coral reefs: new perspectives and implications for coastal management and reef survival. Curr Opin Environ Sustain 7:82-93

D'Elia CF, Webb KL (1977) The dissolved nitrogen flux of reef corals. Proc $3^{\text {rd }}$ Int Coral Reef Symp, Miami 1: 325-330

Davies PS (1991) Effects of daylight variations on the energy budgets of shallow water corals. Mar Biol 108: 137-144

* Davy SK, Lucas IAN, Turner JR (1996) Carbon budgets in temperate anthozoan-dinoflagellate symbioses. Mar Biol 126:773-783

* DeFilippo L, Burmester EM, Kaufman L, Rotjan, RD (2016) Patterns of surface lesion recovery in the Northern Star Coral, Astrangia poculata. J Exp Mar Biol Ecol 481:15-24 
Delignette-Muller ML, Dutang C (2015) fitdistrplus: an R package for fitting distributions. J Stat Softw 64:1-34

DeNiro MJ, Epstein S (1978) Influence of diet on the distribution of carbon isotopes in animals. Geochim Cosmochim Acta 42:495-506

Dimond J, Carrington E (2008) Symbiosis regulation in a facultatively symbiotic temperate coral: zooxanthellae division and expulsion. Coral Reefs 27:601-604

Erez J (1978) Vital effect on stable-isotope composition seen in foraminifera and coral skeletons. Nature 273:199-202

Ezzat L, Maguer JF, Grover R, Ferrier-Pagès C (2015) New insights into carbon acquisition and exchanges within the coral-dinoflagellate symbiosis under $\mathrm{NH}_{4}{ }^{+}$and $\mathrm{NO}_{3}{ }^{-}$ supply. Proc R Soc B 282:20150610

Ezzat L, Maguer JF, Grover R, Ferrier-Pagès C (2016) Limited phosphorus availability is the Achilles heel of tropical reef corals in a warming ocean. Sci Rep 6:31768

Ezzat L, Fine M, Maguer JF, Grover R, Ferrier-Pagès C (2017) Carbon and nitrogen acquisition in shallow and deep holobionts of the scleractinian coral $S$. pistillata. Front Mar Sci 4:102

Ezzat L, Maguer JF, Grover R, Rottier C, Tremblay P, Ferrier-Pagès C (2019) Nutrient starvation impairs the trophic plasticity of reef-building corals under ocean warming. Funct Ecol 33:643-653

Fabricius KE, Genin A, Benayahu Y (1995) Flow-dependent herbivory and growth in zooxanthellae-free soft corals. Limnol Oceanogr 40:1290-1301

Falkowski PG, Dubinsky Z, Muscatine L, Porter JW (1984) Light and the bioenergetics of a symbiotic coral. Bioscience 34:705-709

Ferrier-Pagès $C$, Peirano $A$, Abbate $M$, Cocito $S$ and others (2011) Summer autotrophy and winter heterotrophy in the temperate symbiotic coral Cladocora caespitosa. Limnol Oceanogr 56:1429-1438

Fine M, Loya Y (2002) Endolithic algae: an alternative source of photoassimilates during coral bleaching. Proc R Soc B 269:1205-1210

Fitt WK, Spero HJ, Halas J, White MW, Porter JW (1993) Recovery of the coral Montastrea annularis in the Florida Keys after the 1987 Caribbean 'bleaching event'. Coral Reefs 12:57-64

Fox MD, Elliott Smith EA, Smith JE, Newsome SD (2019) Trophic plasticity in a common reef-building coral: insights from $\delta^{13} \mathrm{C}$ analysis of essential amino acids. Funct Ecol 33:2203-2214

* Gates RD, Baghdasarian G, Muscatine L (1992) Temperature stress causes host cell detachment in symbiotic cnidarians: implications for coral bleaching. Biol Bull (Woods Hole) 182:324-332

* Gattuso JP, Allemand D, Frankignoulle M (1999) Photosynthesis and calcification at cellular, organismal and community levels in coral reefs: a review on interactions and control by carbonate chemistry. Am Zool 39:160-183

*Gace S (2017) Winter quiescence, growth rate, and the release from competition in the temperate scleractinian coral Astrangia poculata (Ellis \& Solander 1786). Northeast Nat (Steuben) 24:B119-B134

Grottoli AG, Rodrigues LJ, Palardy JE (2006) Heterotrophic plasticity and resilience in bleached corals. Nature 440: 1186-1189

Grover R, Maguer JF, Reynaud-Vaganay S, Ferrier-Pagès C (2002) Uptake of ammonium by the scleractinian coral Stylophora pistillata: effect of feeding, light, and ammonium concentrations. Limnol Oceanogr 47:782-790
Grover R, Maguer JF, Allemand D, Ferrier-Pagès C (2003) Nitrate uptake in the scleractinian coral Stylophora pistillata. Limnol Oceanogr 48:2266-2274

* Grover R, Mague JF, Allemand D, Ferrier-Pagès C (2008) Uptake of dissolved free amino acids by the scleractinian coral Stylophora pistillata. J Exp Biol 211:860-865

Hoegh-Guldberg O (1999) Climate change, coral bleaching and the future of the world's coral reefs. Mar Freshw Res 50:839-866

*Houlbrèque F, Ferrier-Pagès C (2009) Heterotrophy in tropical scleractinian corals. Biol Rev Camb Philos Soc 84: $1-17$

Huertas IE, Rouco M, López-Rodas V, Costas E (2011) Warming will affect phytoplankton differently: evidence through a mechanistic approach. Proc R Soc B 278: 3534-3543

* Iglesias-Prieto R, Matta JL, Robins WA, Trench RK (1992) Photosynthetic response to elevated temperature in the symbiotic dinoflagellate Symbiodinium microadriaticum in culture. Proc Natl Acad Sci USA 89:10302-10305

Kopp C, Pernice M, Domart-Coulon I, Djediat C and others (2013) Highly dynamic cellular-level responses of symbiotic coral to a sudden increase in environmental nitrogen. MBio 4:e00052-13

Kopp C, Domart-Coulon I, Escrig S, Humbel BM, Hignette M, Meibom A (2015) Subcellular investigation of photosynthesis-driven carbon assimilation in the symbiotic reef coral Pocillopora damicornis. MBio 6:e02299-14

Kroeker KJ, Kordas RL, Crim RN, Singh GG (2010) Metaanalysis reveals negative yet variable effects of ocean acidification on marine organisms. Ecol Lett 13: 1419-1434

Krueger T, Bodin J, Horwitz N, Loussert-Fonta C and others (2018) Temperature and feeding induce tissue level changes in autotrophic and heterotrophic nutrient allocation in the coral symbiosis-a NanoSIMS study. Sci Rep 8:12710

LaJeunesse TC, Parkinson JE, Reimer JD (2012) A geneticsbased description of Symbiodinium minutum sp. nov. and S. psygmophilum sp. nov. (Dinophyceae), two dinoflagellates symbiotic with Cnidaria. J Phycol 48:1380-1391

* LaJeunesse TC, Parkinson JE, Gabrielson PW, Jeong HJ, Reimer JD, Voolstra CR, Santos SR (2018) Systematic revision of Symbiodiniaceae highlights the antiquity and diversity of coral endosymbionts. Curr Biol 28:2570-2580

KLeal MC, Ferrier-Pagès C, Calado R, Brandes JA, Frischer ME, Nejstgaard JC (2014) Trophic ecology of the facultative symbiotic coral Oculina arbuscula. Mar Ecol Prog Ser 504:171-179

*Leal MC, Hoadley K, Pettay DT, Grajales A, Calado R, Warner ME (2015) Symbiont type influences trophic plasticity of a model cnidarian-dinoflagellate symbiosis. J Exp Biol 218:858-863

Lenth R (2018) emmeans: estimated marginal means, aka least-squares means. $\mathrm{R}$ package version 1.2.3

* Lesser MP, Stat M, Gates RD (2013) The endosymbiotic dinoflagellates (Symbiodinium sp.) of corals are parasites and mutualists. Coral Reefs 32:603-611

Levas S, Schoepf V, Warner ME, Aschaffenburg M, Baumann J, Grottoli AG (2018) Long-term recovery of Caribbean corals from bleaching. J Exp Mar Biol Ecol 506: 124-134

McCloskey LR, Muscatine L (1984) Production and respiration in the Red Sea coral Stylophora pistillata as a function of depth. Proc R Soc B 222:215-230 
Miller DJ, Yellowlees D (1989) Inorganic nitrogen uptake by symbiotic marine cnidarians: a critical review. Proc R Soc B 237:109-125

Muscatine L, Cernichiari E (1969) Assimilation of photosynthetic products of zooxanthellae by a reef coral. Biol Bull (Woods Hole) 137:506-523

Muscatine L, D'Elia CF (1978) The uptake, retention, and release of ammonium by reef corals. Limnol Oceanogr 23:725-734

Muscatine L, Porter JW (1977) Reef corals: mutualistic symbioses adapted to nutrient-poor environments. Bioscience 27:454-460

Muscatine L, Falkowski PG, Porter JW, Dubinsky Z (1984) Fate of photosynthetic fixed carbon in light- and shadeadapted colonies of the symbiotic coral Stylophora pistillata. Proc R Soc B 222:181-202

Oviatt C, Smith L, Krumholz J, Coupland C and others (2017) Managed nutrient reduction impacts on nutrient concentrations, water clarity, primary production, and hypoxia in a north temperate estuary. Estuar Coast Shelf Sci 199:25-34

*Palardy JE, Grottoli AG, Matthews K (2005) Effects of upwelling, depth, morphology and polyp size on feeding in three species of Panamanian corals. Mar Ecol Prog Ser 300:79-89

Palardy JE, Rodrigues LJ, Grottoli AG (2008) The importance of zooplankton to the daily metabolic carbon requirements of healthy and bleached corals at two depths. J Exp Mar Biol Ecol 367:180-188

Pernice M, Meibom A, Van Den Heuvel A, Kopp C, DomartCoulon I, Hoegh-Guldberg O, Dove S (2012) A single-cell view of ammonium assimilation in coral-dinoflagellate symbiosis. ISME J 6:1314-1324

Peterson BJ, Fry B (1987) Stable isotopes in ecosystem studies. Annu Rev Ecol Evol Syst 18:293-320

Porter JW (1976) Autotrophy, heterotrophy, and resource partitioning in Caribbean reef-building corals. Am Nat 110:731-742

R Core Team (2014) R: a language and environment for statistical computing. R Foundation for Statistical Computing, Vienna

Rädecker N, Chen JE, Pogoreutz C, Herrera M, Aranda M, Voolstra CR (2019) Nutrient stress arrests tentacle growth in the coral model Aiptasia. Symbiosis 78:61-64

Radice VZ, Brett MT, Fry B, Fox MD, Hoegh-Guldberg O, Dove SG (2019) Evaluating coral trophic strategies using fatty acid composition and indices. PLOS ONE 14: e0222327

Ralph PJ, Gademann R, Larkum AWD, Schreiber U (1999) In situ underwater measurements of photosynthetic activity of coral zooxanthellae and other reef-dwelling dinoflagellate endosymbionts. Mar Ecol Prog Ser 180:139-147

Raymond J, Siefert JL, Staples CR, Blankenship RE (2004) The natural history of nitrogen fixation. Mol Biol Evol 21: 541-554

Rees TAV (1991) Are symbiotic algae nutrient deficient? Proc R Soc B 243:227-233

Reynaud S, Leclercq N, Romaine-Lioud S, Ferrier-Pagès C, Jaubert J, Gattuso JP (2003) Interacting effects of $\mathrm{CO}_{2}$ partial pressure and temperature on photosynthesis and calcification in a scleractinian coral. Glob Change Biol 9: 1660-1668

Reynaud S, Martinez P, Houlbrèque F, Billy I, Allemand D, Ferrier-Pagès $C$ (2009) Effect of light and feeding on the nitrogen isotopic composition of a zooxanthellate coral: role of nitrogen recycling. Mar Ecol Prog Ser 392: 103-110

Sangsawang L, Casareto BE, Ohb H, Vu H and others (2017)

${ }^{13} \mathrm{C}$ and ${ }^{15} \mathrm{~N}$ assimilation and organic matter translocation by the endolithic community in the massive coral Porites lutea. R Soc Open Sci 4:171201

Schlichter D, Zscharnack B, Krisch H (1995) Transfer of photoassimilates from endolithic algae to coral tissue. Naturwissenschaften 82:561-564

Schlichter D, Kampmann H, Conrady S (1997) Trophic potential and photoecology of endolithic algae living within coral skeletons. Mar Ecol 18:299-317

Schoepf V, Grottoli AG, Levas SJ, Aschaffenburg MD, Baumann JH, Matsui Y, Warner ME (2015) Annual coral bleaching and the long-term recovery capacity of coral. Proc R Soc B 282:20151887

Sebens KP, Witting J, Helmuth B (1997) Effects of water flow and branch spacing on particle capture by the reef coral Madracis mirabilis (Duchassaing and Michelotti). J Exp Mar Biol Ecol 211:1-28

* Sharp KH, Pratte ZA, Kerwin AH, Rotjan RD, Stewart FJ (2017) Season, but not symbiont state, drives microbiome structure in the temperate coral Astrangia poculata. Microbiome 5:120

* Shashar N, Stambler N (1992) Endolithic algae within corals-life in an extreme environment. J Exp Mar Biol Ecol 163:277-286

Shashar N, Banaszak AT, Lesser MP, Amrami D (1997) Coral endolithic algae: life in a protected environment. Pac Sci 51:167-173

Szmant AM, Ferrer LM, FitzGerald LM (1990) Nitrogen excretion and O:N ratios in reef corals: evidence for conservation of nitrogen. Mar Biol 104:119-127

Szmant-Froelich A, Pilson ME (1977) Nitrogen excretion by colonies of the temperate coral Astrangia danae with and without zooxanthellae. Proc $3^{\text {rd }}$ Int Coral Reef Symp, Miami 1:417-423

Szmant-Froelich A, Pilson ME (1980) The effects of feeding frequency and symbiosis with zooxanthellae on the biochemical composition of Astrangia danae Milne Edwards \& Haime 1849. J Exp Mar Biol Ecol 48:85-97

Szmant-Froelich A, Pilson MEQ (1984) Effects of feeding frequency and symbiosis with zooxanthellae on nitrogen metabolism and respiration of the coral Astrangia danae. Mar Biol 81:153-162

Tanaka Y, Miyajima T, Koike I, Hayashibara T, Ogawa H (2006) Translocation and conservation of organic nitrogen within the coral-zooxanthella symbiotic system of Acropora pulchra, as demonstrated by dual isotopelabeling techniques. J Exp Mar Biol Ecol 336:110-119

Tanaka Y, Grottoli AG, Matsui Y, Suzuki A, Sakai K (2015) Partitioning of nitrogen sources to algal endosymbionts of corals with long-term ${ }^{15} \mathrm{~N}$-labelling and a mixing model. Ecol Modell 309-310:163-169

* Tilstra A, Pogoreutz C, Rädecker N, Ziegler M, Wild C, Voolstra CR (2019) Relative diazotroph abundance in symbiotic Red Sea corals decreases with water depth. Front Mar Sci 6:372

* Tremblay P, Grover R, Maguer JF, Legendre L, FerrierPagès $C$ (2012) Autotrophic carbon budget in coral tissue: a new ${ }^{13} \mathrm{C}$-based model of photosynthate translocation. J Exp Biol 215:1384-1393

Tremblay P, Grover R, Maguer JF, Hoogenboom M, Ferrier-Pagès C (2014) Carbon translocation from symbiont to host depends on irradiance and food availability in 
the tropical coral Stylophora pistillata. Coral Reefs 33: $1-13$

Vitousek PM, Howarth RW (1991) Nitrogen limitation on land and in the sea: How can it occur? Biogeochemistry 13:87-115

Wang JT, Douglas AE (1999) Essential amino acid synthesis and nitrogen recycling in an alga-invertebrate symbiosis. Mar Biol 135:219-222

Warner ME, Fitt WK, Schmidt GW (1999) Damage to photosystem II in symbiotic dinoflagellates: a determinant of

Editorial responsibility: Peter Edmunds,

Northridge, California, USA

Reviewed by: 3 anonymous referees coral bleaching. Proc Natl Acad Sci USA 96:8007-8012

Yellowlees D, Rees TAV, Fitt WK (1994) Effect of ammonium-supplemented seawater on glutamine synthetase and glutamate dehydrogenase activities in host tissue and zooxanthellae of Pocillopora damicornis and on ammonium uptake rates of the zooxanthellae. Pac Sci 47(3): 291-295

Y Yellowlees D, Rees TAV, Leggat W (2008) Metabolic interactions between algal symbionts and invertebrate hosts. Plant Cell Environ 31(5):679-694

Submitted: November 6, 2020

Accepted: April 19, 2021

Proofs received from author(s): July 16, 2021 